\title{
Madness and Sexual Psychopathies as the Magnifying Glass of the Normal: Italian Psychiatry and Sexuality c.1880-1910
}

\author{
Chiara Beccalossi*
}

\begin{abstract}
Summary. By focusing on Italian psychiatric debates about sexual inversion this article shows how Italian psychiatrists came to argue that there was no clear-cut boundary between normal sexual behaviour and sexual perversion, and traces the debates and fields of knowledge that contributed to the development of such a position. First, it shows how French psychiatry shaped Italian views on sexual psychopathies. Second, it demonstrates that in Italy, psychiatric research on so-called sexual psychopathies was from its inception part of a wider debate about the blurred boundary between sanity and insanity. Third, it reveals how sexologists embraced various theories of evolution, which implied that sexual perversions were latent in any normal individual. The article argues that despite the fact that in Italy same-sex desires were pathologised in the last three decades of the nineteenth century, historical accounts that emphasise such a pathologisation obscure psychiatric positions that endeavoured to normalise same-sex desires.
\end{abstract}

Keywords: Italian psychiatry; sexology; homosexuality; sexual inversion; normality; Cesare Lombroso; Enrico Morselli; Guglielmo Cantarano; Eugenio Tanzi

The emergence of the modern notion of sexuality was closely linked to nineteenth-century psychiatric studies of sexual variations, in particular same-sex desires. ${ }^{1}$ Various medical disciplines helped to prepare the ground for late nineteenth-century psychiatrists' concern with the influence of the sexual instinct on human behaviour. Forensic medicine, venereology and public hygiene, to name just three such disciplines — reinforced by persistent Malthusian preoccupations about the size of the population and the question of birth control-laid the foundations for late nineteenth-century psychiatrists systematically to explore various forms of non-reproductive sexual behaviour. In addition to these strictly medical disciplines, criminal anthropology, with its questioning of the principle that the individual could exercise free will, came to explain human deviances as biologically driven and contributed to the increasing psychiatric interest in same-sex desires.

\footnotetext{
* Department of History, Philosophy and Religion, Oxford Brookes University, Tonge Building, Gispy Lane, Oxford OX3 OBP, UK. Email: cbeccalossi@brookes.ac.uk

Chiara Beccalossi is a Lecturer in the History of Medicine at the Centre for Health, Medicine and Society: Past and Present (Department of History, Philosophy and Religion) at Oxford Brookes University. She works on the history of sexuality, medicine and human sciences in Modern Britain and Europe, with a special focus on comparative and transnational history. She is the author of Female Sexual Inversion: Same-Sex Desires in Italian and British Sexology, ca. 1870-1920 (2012), as well as a number of articles on the history of medicine and sexuality.
}

${ }^{1}$ Michel Foucault, The Will to Knowledge, History of
Sexuality, vol. 1, trans. Robert Hurley (Harmondsworth:
Penguin Books, 1998); Arnold Davidson, The Emergence of Sexuality: Historical Epistemology and Formation of Concepts (Cambridge, MA: Harvard University Press, 2001). 
Historians have written extensively on the pathologisation of same-sex desires in the last three decades of the nineteenth century in Europe and North America. However, homosexuality was not invariably equated with pathology and, by the end of the century, not only self-identified homosexuals but also some psychiatrists were increasingly given to questioning the conflation of same-sex desires with mental pathology. I have shown elsewhere how, by the beginning of the 1890s, some European medical men, the Frenchman Alfred Binet among them, had come to argue that sexual perversions were nothing but an exaggeration of a normal tendency and that this meant that the difference between the normal and the pathological was simply one of degree. ${ }^{2}$

In a recent article, the historian Harry Oosterhuis has rightly moved away from an emphasis on the psychiatric pathologisation of same-sex desires in the late nineteenth century. According to Oosterhuis the defining characteristics of sexual modernity took shape in Germany in the second half of the nineteenth century, in the work of Richard von Krafft-Ebing and Albert Moll. In the 1890s, Moll elaborated upon Krafft-Ebing's pioneering studies, causing 'a shift from a psychiatric perspective in which deviant sexuality was explained as a derived, episodic and more or less singular symptom of a more fundamental mental disorder, to a consideration of perversion as an integral part of a more general, autonomous and continuous sexual instinct.' Oosterhuis goes on to state that 'Before Henry Havelock Ellis and Sigmund Freud had expressed similar views, it was primarily through the writings of Krafft-Ebing and Moll that a new understanding of human sexuality emerged. ${ }^{3}$ Oosterhuis shows that German psychiatric theories of same-sex desires were 'far from being static and coherent', and that in the mid-1890s Krafft-Ebing and Moll moved away from the view that same-sex desires were a sign of degeneration. He further suggests that in the work of Krafft-Ebing and Moll, the difference between normal and abnormal sexual desires was not so much quantitative and absolute, but rather 'quantitative and gradual'.

While overall, I agree with Oosterhuis's account of the existence and significance of the concept that the difference between normal and abnormal sexuality was 'quantitative and gradual' within late nineteenth-century psychiatric discourses, such an approach to sexual inversion was not the exclusive preserve of Krafft-Ebing and Moll, nor, indeed, of German psychiatry either. The view that there existed only a quantitative difference between normality and sexual variations emerged in other national contexts and had a long historical trajectory firmly positioned within debates on the nature of insanity, within new psychiatric diagnoses such as monomania and moral insanity, and within various theories of evolution. ${ }^{4}$ In the second half of the nineteenth century Italian psychiatrists blurred the boundary between normal sexual behaviour and sexual perversions in the context of their reflections on the demarcation of sanity from insanity and on the evolutionary meaning of sexual differentiation; of their studies on sexual inversion; and of their general observations on the importance of the sexual instinct in human life. While some

\footnotetext{
${ }^{2}$ Chiara Beccalossi, 'Nineteenth-Century European Psychiatry on Same-Sex Desires: Pathology, Abnormality, Normality and the Blurring of Boundaries', Psychology \& Sexuality, 2010, 1, 226-38. This article's focus is an overview of British, French and German psychiatry and homosexuality.
}

\footnotetext{
${ }^{3}$ Harry Oosterhuis, 'Sexual Modernity in the Works of Richard von Krafft-Ebing and Albert Moll', Medical History, 2012, 56, 135.

${ }^{4}$ Beccalossi, 'Nineteenth-Century European Psychiatry'.
} 
overtones may well be specific to the Italian case, this last remains instructive insofar as it points to those broader medical debates that allowed psychiatrists to problematise the boundary between normal and abnormal at the end of the nineteenth century.

This paper is not concerned to establish which psychiatrist first unsettled the strict separation of the normal from the pathological sexual instinct, or in which country this first occurred. Rather, the aim is to situate debates on the normal and abnormal in a long trajectory within psychiatry, and to bring to light the epistemological framework that allowed latenineteenth century sexologists to frame such discourses. Historians of sexology have overlooked this long trajectory, which dates back to eighteenth-century faculty psychology.

In The Will to Power, the philosopher Friedrich Nietzsche, echoing Claude Bernard's doctrine, stated: 'It is the value of all morbid states that they shows us under a magnifying glass certain states that are normal—but not easily visible when normal'. ${ }^{5}$ This notion that disease could function as a lens through which the normal could be observed informed, not without unresolved contradictions, late nineteenth-century Italian psychiatric research into the so-called sexual psychopathies. Indeed, psychiatrists believed that madness might sometimes exaggerate certain characteristics present in all healthy individuals. To a certain extent, this assumption led psychiatrists to narrow the gap between the normal and the insane. Conversely, psychiatrists also strove to separate the normal and the insane further by attributing the normal person to the higher peaks of evolution, while confining human deviancies, including sexual psychopathies, to the lowest rungs of human development. Detailed catalogues with endless descriptions of different kinds of 'degenerates', from the criminal to the insane, served to bring the deviant to the fore, and thereby drew a line between the realms of the normal and the pathological.

The presence of these two contradictory discourses, the one assimilating the insane into the normal realm and the other differentiating the insane from the normal, is all too evident in late nineteenth-century Italian sexological studies on sexual inversion. Yet this ambivalence is often obscured in historical accounts of Italian psychiatry of the period. One dominant theme in the historiography has been the way in which Italian psychiatry came to define notions of normality. This research has grown out of an interest in how Italian psychiatric knowledge came to shape notions of gender within the positivistic medical sciences. ${ }^{6}$ In

\footnotetext{
${ }^{5}$ Friedrich Nietzsche, The Will to Power, W. Kaufmann and R. J. Hollingdale (trans) (New York: Vintage, 1968), 33 (first published in 1901); Georges Canguilhem, The Normal and the Pathological, C. R. Fawcett (trans) (New York: Zone Books, 1989), 45.

'Bruno Wanrooij, '“La carne vedova”, immagini della sessualità femminile', Belfagor, 1987, 42, 454-66; BrunoWanrooij, 'La passione svelata: sessualità, crimine ed educazione in Italia tra Ottocento e Novecento', Sanità scienza e storia, 1988, 5, 393-428; Valeria P. Babini et al., La donna nelle scienze dell'uomo (Milan: Franco Angeli, 1989); Bruno Wanrooj, Storia dell pudore: La questione sessuale in Italia 1860-1940 (Venice: Marsilio 1990); Paolo Sorcinelli, Storia e sessualità: casi di vita, regole e tragressioni tra Ottocento e Novecento (Milan: Mondadori, 2001); Vinzia Fiorino, Matti, indemoniate, vagabondi: dinamiche di internamento manicomiale tra Otto e Novecento (Venice:
}

Saggi Marsilio, 2002); Lisa Roscioni, Il governo della follia: ospedali, medici e pazzi nell'età moderna (Milan: Mondadori, 2003). For works on Italian psychiatry in English: Annamaria Tagliavini, 'Aspects of the History of Psychiatry in Italy in the Second Half of the Nineteenth Century', in Roy Porter, W.F. Bynum and Michael Shepherd, eds, Anatomy of Madness: Essays in the History of Psychiatry (London: Tavistock Publications, 1985), II, 175-96; Patrizia Guarnieri, 'A History of Psychiatry in Italy', History of Psychiatry, 1991, 2, 289-301; Patrizia Guarnieri, A Case of Child Murder: Law and Science in Nineteenth-Century Tuscany (Cambridge: Polity Press, 1993); Linda Reeder, 'Unattached and Unhinged: The Spinster and the Psychiatrist in Liberal Italy, 1860-1922', Gender \& History, 2012, 24, 187-204. This historiographical trend has perhaps been especially preoccupied with how female deviancy fixed notions of normalcy. By the same token, it has 
the last decade, a growing number of historians have begun to shift their attention to how it was that medical men defined sexual psychopathies by focusing on same-sex desires. ${ }^{7}$ Broadly speaking, both historiographical trends have tended to highlight the propensity of positivistic psychiatrists to pathologise non-reproductive sexual behaviours and to stigmatise those individuals, foremost among them homosexuals, who did not conform to accepted medical norms.

Without doubt, in Italy as in other European countries such as France and Germany, a process of the pathologisation of same-sex desires gathered pace in the last three decades of the nineteenth century. In Italy this process started with the publication of Arrigo Tamassia's important 1878 article on sexual inversion. ${ }^{8}$ This seminal work closely scrutinised Carl Westphal's original diagnosis of 'Conträre Sexualempfindung'. Tamassia argued that sexual inversion was a fully-fledged mental disorder and not, despite his German colleague's suggestion in 1869, a 'partial insanity'. ${ }^{9}$ Tamassia believed that sexual inversion was a genuine form of mental pathology for two main reasons. First, because sexual inverts acknowledged themselves to be members of the one sex but displayed all the psychological attributes of the other. ${ }^{10}$ Second, because in sexual inverts 'the morbid impulse is ... accompanied by such mental distress that they do not achieve an exact knowledge of their relationship with the species, and even if they do attain it, they lack the [requisite] will power'. ${ }^{11}$ In other words, sexual inverts could not resist sexual urges contrary to the 'natural' reproductive instinct. Yet, perhaps because professional historians have only recently addressed the history of homosexuality in Italy, they have tended to overlook an interesting phenomenon within psychiatry, namely, the existence of a number of Italian psychiatrists who called into question what we today define as the pathologisation of same-sex desires. Indeed, by the turn of the twentieth century, some Italian psychiatrists, including a few who were prominent in their profession,

largely overlooked the emergence of sexology at the end of the nineteenth century. Given that Italy, in the last decade of the nineteenth century, produced some of the most significant thinkers so far as the modern idea of sexuality is concerned, Cesare Lombroso among them; and given the extensive historical literature produced by historians working especially on British, French, German and North American sexology since the early 1980s, this lacuna is more than a little disconcerting. ${ }^{7}$ Nerina Milletti, 'Analoghe sconcezze. Tribadi, saffiste, invertite e omosessuali: categorie e sistemi sesso/ genere nella rivista di antropologia criminale fondata da Cesare Lombroso (1880-1949)', DWF Donnawomanfemme, 1994, 4, 50-122; Mary Gibson, 'Labelling Women Deviant: Heterosexual Women, Prostitutes and Lesbians in Early Criminological Discourse', in Perry Willson, ed., Gender, Family and Sexuality: The Private Sphere in Italy, 1860-1945 (Basingstoke: Palgrave Macmillan, 2004), 89-104; Lorenzo Benadusi, IInemico delI'uomo nuovo. L'omosessualità nell'esperimento totalitario fascista (Milan: Feltrinelli, 2005), 35-87; Laura Schettini, /l gioco delle parti. Travestimenti e paure sociali tra Otto e Novecento (Milan: Mondadori, 2011), 141-73; Chiara Beccalossi, Female Sexual Inversion: Same-Sex Desires in Italian and British Sexology, ca. 1870-1920 (Basingstoke: Palgrave Macmillan,
2012). Interestingly enough there are perhaps more historical studies of nineteenth-century female homosexuality than of male homosexuality, an imbalance possibly due to the complexity of the task of investigating the different laws existing on the Peninsula before and after unification. See, Benadusi, // nemico, 98-100.

${ }^{8}$ Prior to Tamassia's work on sexual inversion, some cursory medical observations on same sex desires in Italy might be found, but Tamassia was the first to systematise recent studies on sexual inversion. See Beccalossi, Female Sexual Inversion, 51-54, 67-68.

${ }^{9} \mathrm{Carl}$ Westphal, 'Die conträre Sexualempfindung: Symptom eines neuropathischen (psychopathischen) Zustandes. Archiv für Psychiatrie und Nervenkrankheiten, 2, 73-108 (M.A.) In Lombardi-Nash, Sodomites and Urnings: Homosexual Representations in Classic German Journals (New York: Harrington Park Press, 2006, originally published in 1869),108-9; Arrigo Tamassia, 'Sull'inversione dell'istinto sessuale', Rivista sperimentale di freniatria e di medicina legale in relazione con l'antropologia e le scienze giuridiche e sociali, 1878, 97-102.

${ }^{10}$ Tamassia, 'Sull'inversione dell'istinto sessuale', 97-117.

${ }^{11} \mathrm{Ibid} ., 115$. For a close reading of Tamassia's article: Beccalossi, Female Sexual Inversion, 51-4. 
came to question whether homosexuality was strictly speaking a pathology, though it had clearly been labelled such in the late 1870s. This article discusses how Italian psychiatrists' debates on the blurred boundary between normality, abnormality and pathology eventually served to engender the idea that homosexuality enjoyed an uncertain medical status and could even be considered normal under some circumstances. But before turning to the positivistic psychiatric approaches to homosexuality, it is important to map those early nineteenthcentury ideas which, later in the century, helped to shape the notion that same-sex desires occupied a grey area between the normal and the pathological.

\section{Psychiatry of Passions, Experimental Medicine and Atavism}

First of all, as I mentioned above, late nineteenth-century Italian psychiatrists believed that insanity could be interpreted as an exaggeration of normal behaviour. ${ }^{12}$ This belief was supported by what I would call the 'psychiatry of the passions', a psychiatry which had its most influential proponents in the French alienist Philippe Pinel and his pupil Jean-Etienne Esquirol. Their views on mental illness had not been wholly abandoned by late nineteenthcentury Italian psychiatrists, who sought to understand the relationship between sexual behaviour and mental disorders. Second, Claude Bernard's experimental medicine encouraged Italian psychiatrists to gaze at the pathological in order to understand the normal. There were echoes of Bernard's ideas in late nineteenth-century psychiatric debates on insanity in general, and, more specifically on sexual inversion. Finally, Lombroso's theory of atavism, whereby a normal and civilised individual might revert to a more primitive stage, implied that the boundary between normality and abnormality was unclear. These three factors, combined with the growing number of sexual inversion case histories published each year, called into question the idea that this new medical category was to be classified as a mental pathology.

Italian historians have posited a bipartite division of nineteenth-century psychiatry, distinguishing between early nineteenth-century alienism (a psychiatry concerned with the impact of the passions upon insanity) and late nineteenth-century psychiatry (which adopted an organic approach to mental disorders). ${ }^{13}$ However, the 'psychiatry of the passions' continued to inform the thinking of those late nineteenth-century psychiatrists who had embraced organic medicine. Indeed, historians have pointed out how certain early nineteenth-century concepts like monomania and moral insanity were still current in Italy in the last decades of the century, long after they had been abandoned in France. ${ }^{14}$ The residual influence of the 'psychiatry of the passions' may account in part for the readiness of late-nineteenth-century psychiatrists to doubt the existence of a boundary between normality and insanity, and at the same time to explore the role of the sexual

\footnotetext{
${ }^{12}$ For an overview of the philosophical and medical relationship between the normal and abnormal in nineteenth-century psychiatry: Giovanni Pietro Lombardo and Giovanna Pedone, Normale e patologico nelle teorie della personalita'. Una analisi dei fondamenti storici della psicologia (Laterza: Rome 1996).

${ }^{13}$ Mario Galzigna,'Soggetto di passione, soggetto di follia', Jean-Étienne Dominique Esquirol, Delle passioni (Milano: Mimesis, 2008, original edition 1805), 7-49; Fiorino, Matti, 129-31.
}

\footnotetext{
${ }^{14}$ On momomania and moral insanity in late nineteenthcentury Italian psychiatry: Ugo Fornari, 'Monomania e pazzia morale: il contributo della psichiatria italiana nella seconda meta dell'Ottocento', Criminologia, 1986, 3-49. On monomania in French nineteenthcentury psychiatry: Jan E. Goldstein, Console and Classify: The French Psychiatric Profession in the Nineteenth Century (Chicago: University of Chicago Press, 2001), 152-96.
} 
instinct in the development of psychopathies. Since the 'psychiatry of the passions' influenced late-nineteenth-century Italian sexology, let me now turn to it.

According to the classical view of madness, the indivisibility of the soul meant that the insane were by definition totally deranged; they could not be partially deranged. Moreover, an insane person could neither be healed nor transformed into a normal individual. Sanity and insanity were two separate ontological states. Towards the end of the eighteenth century, the faculty psychology proposed by Thomas Reid and by the work of Robert Whytt and William Cullen provided a new model for conceiving insanity. While not denying the unity of the soul, authors like Reid introduced the 'operational notion' of faculties, dividing them into cognition, emotion and volition. ${ }^{15}$ This was a conceptual breakthrough, first of all because it fostered the belief that there might be disorders of an emotional or mood faculty that did not involve the presence of an impaired intellect. This ran counter to the classical view of insanity, according to which madness was characterised by the presence of delirium. Crucially at the end of the nineteenth century, sexual inversion was seen as an emotional disorder, one that did not necessarily involve a damaged intellect. Second, Reid's faculty psychology inspired alienists like Pinel and Esquirol to explore the full range of insanities without delirium. Pinel initiated the study of the folies raisonnantes and Esquirol introduced new diagnoses such as monomania. ${ }^{16}$ These new frameworks for diagnosis allowed alienists to conceive of the insane as deranged but not completely estranged from-or essentially other to-the normal human condition. Indeed, the basic assumption of early nineteenth-century moral treatment, as conceived by French alienists, was that it was possible to transform an insane person whose disorder had not been caused by organic lesions, as in the case of idiotism, into a sane and functioning individual, their cure being hastened by the favourable conditions the asylum provided. ${ }^{17}$ In Esquirol's work, in particular, less severe forms of insanity were construed as states not so far removed from the norm. The insane projected a sort of distorted image of the normal man, but they were essentially of the same nature.

Across the Channel the British physician and ethnologist, James Cowles Prichard, developed a similar diagnosis to those of early-nineteenth-century French alienists and introduced the concept of moral insanity, a state of 'morbid perversion of the feelings', which remained very popular amongst late-nineteenth-century Italian psychiatrists, in particular those who worked on sexual psychopathies. ${ }^{18}$ In brief, those early nineteenth-century psychiatrists who elaborated new diagnoses like monomania or moral insanity, the diseases of the will or of the emotions, extended the domain of psychiatry by introducing new disorders. On the other hand they brought the normal and the pathological closer by assuming that monomaniacs or the morally insane could function intellectually in their everyday tasks, and by

\footnotetext{
${ }^{15}$ David Healy, Mania: A Short History of Bipolar Disorder (Baltimore: John Hopkins University Press, 2008), 38-9.

${ }^{16} \mathrm{G}$. E. Berrios, 'European Views on Personality Disorders: A Conceptual History', Comprehensive Psychiatry, 1993, 34, 18-20.

${ }^{17}$ Goldstein, Console, 65-116.

${ }^{18}$ Fabio Stock, La formazione della psichiatria (Rome: ॥ Persiero Scientifico, 1981), 69. On Prichard's concept
}

\begin{abstract}
of moral insanity: Hannah Franziska Augstein, 'J.C. Prichard's Concept of Moral insanity: A Medical Theory of the Corruption of Human Nature', Medical History, 1996, 40, 311-43. I am not suggesting that early nineteenth-century psychiatry developed in the same way in all European countries, but merely summarising what historians of psychiatry have noticed in different national contexts.
\end{abstract}


firmly believing that these kinds of insane person could be healed. ${ }^{19}$ In these terms, health and monomania, for example, were not two distinct states. Finally, psychiatric studies of monomania and moral insanity occasionally touched upon non-reproductive sexual conduct such as same-sex desires, although in the first half of the nineteenth century there had been no systematic medical study of same-sex desires. ${ }^{20}$ It is within this interest in moral insanity that sexual inversion was first observed in Italy. Indeed, prior to studying sexual inversion, Tamassia had worked on moral insanity. ${ }^{21}$

There are other important implications of these studies that historians interested in the history of sexology have often overlooked. In the light of Reid's faculty psychology and Esquirol's and Prichard's works on monomania and moral insanity, psychiatrists looked at conditions that did not display an anatomically localised pathology. These disorders were functional (affective, volitional and intellectual) disorders. ${ }^{22}$ As Arnold Davidson, in his important account of the emergence of the modern concept of sexuality, has pointed out, functional disorders had permitted the emergence of the so-called sexual perversions, such as sexual inversion, within psychiatric discourses. Davidson has not himself traced functional disorders such as sexual inversion back to faculty psychology or to Esquirol's monomania, yet Reid's faculty psychology and new diagnoses such as monomania may be said to have created the conceptual space within which, late in the nineteenth century, it became possible to conceive of sexual inversion. ${ }^{23}$

The importance of the meaning of functional diseases for the history of sexual inversion can be traced even beyond psychiatry. Claude Bernard's physiology was concerned with the study of the function of organs. Neglecting the study of the tissues and the anatomy of specific organs, the French physiologist was preoccupied in his experimental medicine by research into functions. ${ }^{24}$ Bernard took up the thesis previously advanced by François-Joseph-Victor Broussais, according to which pathological states differ from normal healthy states merely in degree, and he therefore saw the pathological as an alteration of the normal. ${ }^{25}$ To Bernard, pathology was the key to understanding physiology; the pathological was, in his judgement, 'the disturbance of a normal mechanism consisting in a quantitative variation, an exaggeration or attenuation of normal phenomena'. ${ }^{26}$ In other words, illness was nothing more than an excess or defect of some factors requisite for health. ${ }^{27}$ One could say that, just as early nineteenth-

${ }^{19}$ On the diseases of the will: G. E. Berrios and M. Gili, 'Will and Its Disorders: A Conceptual History', History of Psychiatry, 1995, 6, 87-104; Healy, Mania, 37-43. On the way in which these new psychiatric diagnoses such as monomania served to extend the domain of psychiatry, see Goldstein, Console, 152-96.

${ }^{20}$ Philipp Gutmann, 'On the Way to Scientia Sexualis: "On the relation of the sexual system to the psyche in general and to cretinism in particular" (1826) by Joseph Häussler', History of Psychiatry, 2006, 17, 45-53; Ivan Crozier, 'Nineteenth-Century British Psychiatric Writing about Homosexuality before Havelock Ellis: The Missing Story', Journal for the History of Medicine and Allied Sciences, 2008, 65, 65-102; Beccalossi, 'Nineteenth-Century European Psychiatry on Same-Sex Desires: Pathology, Abnormality, Normality and the Blurring of Boundaries'.

${ }^{21}$ Arrigo Tamassia, 'La pazzia morale', Rivista sperimentale di freniatria e di medicina legale in relazione con
I'antropologia e le scienze giuridiche e sociali, 1877, 3, 158-70.

${ }^{22}$ Functional diseases can be described as functional deviations of some kind, Davidson, The Emergence of Sexuality, 1-29.

${ }^{23} \mathrm{lbid}$.

${ }^{24}$ For a study of the concept of function that goes from Bichat to Bernard: William Randall Albury, 'Experiment and Explanation in the Physiology of Bichat and Magendie', Studies in the History of Biology, 1977, 1, 47-131.

${ }^{25}$ Canguilhem, Normal.

${ }^{26}$ lbid., 76.

${ }^{27}$ Ibid., 65-89. Georges Canguilhem criticises Broussais' thesis, which was adopted by a number of medical writers in the nineteenth century, on the ground that it rested upon a confusion between the concept of continuity and that of homogeneity. Broussais' error was due, in Canguilhem's opinion, to his having 
century French alienism implied a unitary vision of normality and insanity, so too did Bernard's experimental medicine imply a unitary vision of health and sickness. As I will show below, Bernard's experimental method informed much of late nineteenth-century Italian psychiatry. It is not a coincidence that one of the very first Italian psychiatric journals was entitled Rivista sperimentale di freniatria e medicina legale in relazione con l'antropologia e le scienze giuridiche e sociali [Experimental Journal of Phreniatry and Legal Medicine Relating to Anthropology and Legal and Social Sciences], thereby indicating that experimentation was essential to Italian psychiatry.

If, on the one hand, the pathological and the healthy were seen as closely related states in early nineteenth-century psychiatric thought and practice, on the other hand, psychiatrists began to re-impose a division in the mid-nineteenth century. Benedict Morel's work on degeneration posed once again the problem of the incurability of madness. Degeneration could perhaps be prevented, but once it had afflicted a family, inexorable decline was the inevitable outcome. ${ }^{28}$ In Italy the debate about degeneration was intertwined with that of evolution and atavism. The latter theory is indissolubly linked to the name of the most prominent late nineteenth-century psychiatrist and founder of criminal anthropology, Cesare Lombroso. Among other things, Lombroso's contribution to the emergence of sexology is now well documented and I do not propose to devote too much space to it here. ${ }^{29}$ Suffice to say that under the influence of Lombroso's criminal anthropology, Italian psychiatrists described in exhaustive detail the bodily and personality signs of the deviant, with the result that the latter became visible and virtually separate from normal society. According to Lombroso, the degenerate and atavistic insane were throwbacks to a violent and brutal past. Atavism was understood to be the tendency of plants and animals to reproduce ancestral types and, where humanity was concerned, to resemble one's grandparents or greatgrandparents more than one's parents. Yet this view of the evolutionary process had a further implication. Although the normal (white) man had attained the summit of evolution, at the same time he contained the germs of an atavistic creature, since his own individual development recapitulated the historical phases of human civilisation. ${ }^{30}$ Atavism became manifest in the criminal, in the insane person, and in other human deviations, but the civilised 'normal' man was nonetheless himself at risk of reverting to the ancestral type. Many pages would be needed to analyse in full the tensions and contradictions implicit in Lombroso's work on atavism. To be brief, and in order to clarify the concept of atavism, Lombroso's belief that the normal man could revert to an atavistic beast was vividly captured by Robert Louis Stevenson in his terrifying novel, The Strange Case of Dr Jekyll and Mr Hyde (1886). The fictional character of Edward Hyde embodied the figure of Lombroso's atavistic

failed to realise that just because one state can be derived from another by a continuous series of quantitative changes, it does not follow that the two states do not differ qualitatively. Gary Gutting, Michel Foucault's Archaeology of Scientific Knowledge (Cambridge: Cambridge University Press, 1989), 46.

${ }^{28}$ For the importance of degeneration in Italian psychiatry, see Daniel Pick, Faces of Degeneration: A European Disorder, c. 1848-1918 (Cambridge: Cambridge University Press, 1989).
${ }^{29}$ Milletti, 'Analoghe sconcezze'; Gibson, 'Labelling'; Benadusi, II nemico, 35-87; Beccalossi, Female Sexual Inversion.

${ }^{30}$ For recent studies on Lombroso see: Mary Ginson, Born to Crime: Cesare Lombroso and the Origins of Biological Criminology (Westport: Praeger, 2002); Delia Frigessi, Cesare Lombroso (Turin: Einaudi, 2003); David Horn, The Criminal Body: Lombroso and the Anatomy of Deviance (New York: Routledge, 2003); Silvano Montaldo and Paolo Tappero, eds, Cesare Lombroso cento anni dopo (Turin: UTET, 2009). 
criminal, and the story alluded to the danger that any normal and respectable individual, such as Dr Jekyll, might revert to the condition of a monstrous creature, since the latter lurked in each and every human being.

\section{Madness as a Microscope that Magnifies Normal Human Characteristics} As I will show in the rest of this paper, the study of sexual psychopathies grew out of the tensions mapped above. ${ }^{31}$ Late nineteenth-century Italian psychiatrists believed that madness could help their profession understand the normal human condition. In parallel, those working in the emerging field of sexology believed that research into the various forms of sexual psychopathies might shed light on normal sexuality, which was strongly linked to reproduction. While such an understanding of human sexuality allowed a number of psychiatrists to claim that there was no clear-cut boundary between normal sexual behaviour and sexual perversion, much debate surrounded the search for such a boundary.

In Italy, the official establishment of psychiatry coincided with the earliest research into sexual inversion. The first formally constituted Italian psychiatric association, the Società di Freniatria Italiana [Italian Phreniatric Association], was founded in 1873. Two years later, the Rivista sperimentale di freniatria was launched by Carlo Livi, supervisor of the S. Lazzaro asylum in Reggio Emilia, and his two assistants, Enrico Morselli and Augusto Tamburini. ${ }^{32}$ This journal functioned as the official periodical of the Società di Freniatria Italiana. In this period Italian psychiatrists adopted the term phreniatry, instead of psychiatry or psychology, to indicate their belief that mental disorders had an organic origin. ${ }^{33}$ Indeed, in the second half of the nineteenth century, the dominant position within Italian psychiatry interpreted mental disorders as illnesses of the cerebral organ rather than as illnesses of the soul or psyche. ${ }^{34}$ The use of the term 'experimental' in the name of the journal indicated the psychiatrists' ambition to make their discipline an experimental medical science. Livi's programmatic article on 'The experimental method in phreniatry and legal medicine', synthesised what experimental psychiatry aspired to be at the time. In this article, published in the very first issue of the Rivista sperimentale di freniatria, Livi explained that the journal promoted neuro-pathology, pathological anatomy with its search for brain lesions, histology, and the clinical and experimental physiology of the nervous system. It also sought to support the most advanced scientific research in Italy and fostered an experimental psychiatry based upon anthropometry, somatic examination, and statistics. Livi also outlined the tools of the experimental method and explained that only 'experimentation', 'clinical observation', and the 'microscope' had the power to advance the scientific status of psychiatry. ${ }^{35}$

\footnotetext{
${ }^{31}$ Anyone aspiring to write a history of the medicalisation of same-sex desires would need to unpick these trends.

${ }^{32}$ Italian alienists did not use the term 'psychiatry' because they wanted to distance themselves from notions such as 'psyche' and 'psychological', employed by, for example, the French Société médico-psychologique. Tagliavini, 'History of Psychiatry', 179. On Livi: Patrizia Guarnieri, Child Murder: Lawand Science in NineteenthCentury Tuscany (Cambridge: Polity Press, 1993), 74-7.

${ }^{33}$ Francesco De Peri, 'Il medico e il folle: introduzione psichiatrica, sapere scientifico e pensiero medico fra Otto e Novecento', Franco Della Peruta, ed., Storia d'Italia. Annali 7 (Turin: Einaudi 1984), 1088.
}

\footnotetext{
${ }^{34}$ There has been a debate on to what extent late-nineteenth-century Italian psychiatry embraced organicism, see for example: Valeria P. Babini, 'Organicismo e ideologie nella psichiatria italiana dell'Ottocento, Filippo Maria Ferro et al., eds, Passioni della mente e della storia (Milan: Vita e Pensiero, 1989), 331-50; Guarnieri, Child Murder.

${ }^{35}$ Carlo Livi, 'Del metodo sperimentale in freniatria e medicina legale. Discorso che potrebbe servire a uso di programma', Rivista sperimentale di freniatria e di medicina legale in relazione con l'antropologia e le scienze giuridiche e sociali, 1875, 1, 4.
} 
If psychiatry hoped to become a science of pure observation, it would have to embrace the experimental method. The bodies of the mentally ill held the key to behavioural disturbances, and had thus to be examined and measured with great precision. Livi asserted that psychiatry should study the lunatic patient by enquiring into the causes and symptoms of mental illness, the somatic diseases that accompanied mental disorders and their possible remedies. $^{36}$

Moreover, this article effectively conveyed the basic idea that the systematic study of mental disorders might be a source of insight not only into the behaviour of the insane secluded in asylums, but also — and even primarily_into that of normal people. This idea was shared by late nineteenth-century psychiatrists interested in the study of sexual perversions. Livi's article indicated how the study of mental disorders was important for society in general, since it permitted an understanding of human nature as such. 'The inner darkness of the human spirit', Livi wrote, 'is more readily discovered in the lunatic than in the healthy person. Factors such as civilisation, education, prejudices, and social conventions have removed certain structures and shapes from the primitive or natural man; madness restores this darkness to him.' Madness gave the psychiatrist 'the chance to anatomise, separate into its intimate parts and study, this wonderful synthesis of the human intellect ...', since it was, Livi revealingly wrote, 'a disease that dissolves the natural ties of the process of thinking and of the will: like a surgical knife it separates, analyses the human mind; but as a microscope magnifies, it exaggerates too. ${ }^{37}$

By advancing the claim that psychiatry might reveal the most secret aspects of the human condition, Livi was stressing the intrinsic value of psychiatric research. In a sense, this was a rhetorical exercise to promote the relatively new discipline of psychiatry in Italy. Moreover, Livi was advocating a new and more scientific type of psychiatry. Associating the phenomenon of madness with medical instruments such as the surgical knife and, more especially, the microscope, was a way of foregrounding the positivistic psychiatrists' commitment to experimental methods of anatomical and physiological research. ${ }^{38}$ The reference to these tools highlighted the scientific ambitions psychiatrists nursed for their fledgling discipline. Yet Livi was also saying something more. He was claiming that the madman was in fact a living laboratory for the alienist: in the madman, nature had dissolved artificial conditions created by cultural constraints. Madness being simply certain normal conditions writ large, observing how deranged people behaved could lead to a greater understanding of the very essence of human nature. Therefore, according to Livi's conception there were no set boundaries between mental illness and sanity. In the last decades of the nineteenth century such an emphasis on the link between normal and pathological states was crucial for those psychiatrists who had begun to study the relationships between mental disorders and the sexual instinct.

\section{Sexual Psychopathies as an Exaggeration of the Tendencies of the Healthy Individual}

Livi's article touched upon another point when he argued that psychiatric research was relevant to the business of government because it might help an administration to tackle social

\footnotetext{
${ }^{36} / \mathrm{bid}$.

${ }^{37}$ Ibid., 5-6.
}

${ }^{38}$ Tagliavini, 'History of Psychiatry', 179. 
disorder. Up until then, Livi explained, crime had been studied as an abstract entity. The offender was merely punished, instead of being 'scrupulously' studied 'not in the actual moment of the crime, but in all his antecedent life'. Psychiatry could advance understanding of the social and psychological motives behind crime. ${ }^{39}$ Thus, psychiatrists were encouraged to step beyond the boundaries of their own discipline and venture into the field of the human and social sciences. ${ }^{40}$ In the late 1870 s, pursuing this interest in the human and social sciences and in the study of crime, the Rivista sperimentale di freniatria collaborated with the criminal anthropologist Lombroso, who at the time was lecturing at the University of Pavia. ${ }^{41}$ During this period Lombroso was developing a research programme that aimed to establish a nexus between psychiatry and the natural sciences in general, and anthropology in particular. ${ }^{42}$ Such an interdisciplinary approach became typical of the journal Archivio di psichiatria, scienze penali ed antropologia criminale per servire allo studio dell'uomo alienato e delinquente [Archive of Psychiatry, Penal Sciences and Criminal Anthropology to Serve the Study of the Mentally III and Offender], which was founded by Lombroso himself in 1880. Amongst other things, the Archivio di psichiatria fostered the study of sexual psychopathologies from its inception. It regularly featured original contributions from Italian medical men and reviewed foreign works in the field. From 1899 onwards, the Archivio devoted a specific section to the subject under the heading 'Psicopatie sessuali' [Sexual Psychopathies]. As editor of the journal, Lombroso was especially concerned with popularising foreign sexologists such as Krafft-Ebing, reworking case histories known to the international medical community, and publishing original Italian case studies and observations. ${ }^{43}$

In 1881, Lombroso published a seminal essay in Archivio di psichiatria entitled 'L'amore nei pazzi' [Love in the Insane], a widely influential piece that continued to be acknowledged for many years to come in important sexological texts such as Krafft-Ebing's Psychopathia Sexualis. ${ }^{44}$ Lombroso's article tacitly followed earlier attempts to classify various forms of non-procreative sexual behaviour. In 1844, the Russian physician Heinrich Kaan had published Psychopathia Sexualis, which was written in Latin and divided sexual aberrations into six main categories: onanism; pederasty (meaning desire for children); lesbian love (meaning both male and female same-sex desires); necrophilia; bestiality; and love for statues. ${ }^{45}$ In 1877, Krafft-Ebing had limited sexual perversions to four main groups: those lacking a sexual drive; those characterised by an abnormal increase in sexual drive (such

\footnotetext{
${ }^{39}$ Livi, 'Del metodo', 7.

${ }^{40}$ On the question of how borders between fields of knowledge are created, demarcated, and contested: T. F. Gieryn, Cultural Boundaries of Science: Credibility on the Line (Chicago: University of Chicago Press, 1999). On the conflict between law and Italian psychiatry: Guarnieri, Child Murder. On the conflict between sexology and psychoanalysis: Ivan Crozier, 'Taking Prisoners: Havelock Ellis, Sigmund Freud, and the Politics of Constructing the Homosexual, 1897-1951', Social History of Medicine, 2000, 13, 447-66.

${ }^{41}$ On Livi's criticism to Lombroso: Guarnieri, Child Murder, 149.

${ }^{42}$ De Peri, 'll medico', 1184-8.

${ }^{43}$ Aside from his role as editor of this journal, Lombroso played a key part in popularising sexology in Italy by
}

supporting and contributing to the translation of major foreign works. For instance, in 1889 he sponsored the publication of the Italian translation of Krafft-Ebing's Psychopathia Sexualis through Bocca, a well-respected medical publishing house. Cesare Lombroso, 'Introduzione', Richard von Krafft-Ebing, Le psicopatie sessuali, E. Sterz and L. Waldhart (trans) (Turin: Bocca, 1889), xi-xxxii.

${ }^{44}$ Richard von Krafft-Ebing, Psychopathia Sexualis, C. G. Chaddock (trans) (Philadelphia: Davis, 1893), 222.

${ }^{45}$ Michel Foucault, Abnormal. Lectures at the Collège de France, 1974-75, G. Burchell (trans) (London: Verso, 2003), 279. 
as nymphomania); those in which the sexual instinct appeared abnormally early (e.g. before puberty) or in old age; and finally, the perversions in which sexual instinct was not 'appropriately' directed towards the preservation of the species (e.g. necrophilia, lust, murder, and sexual inversion). ${ }^{46}$ Lombroso's classification resembled Kaan's more than KrafftEbing's, and he recognised five main kinds of sexual deviation: 'necrofilomanie' (broadly speaking, necrophilia); subjects who were 'eroto-maniaci' (manifesting a form of mystical love); 'amore zoologico' (love for statues or animals); 'amore paradosso' (literally 'paradox love', broadly speaking fetishism and exhibitionism); and finally 'amore invertito' (literally, 'inverted love'). Surprisingly enough, in his cataloguing of the different forms of sexual perversions, Lombroso did not place the normal and the pathological in two clearly distinct realms. ${ }^{47}$

Indeed, in 'L'amore nei pazzi' Lombroso extended to sexual psychopathies what Livi had already said with regard to insanities in general, arguing that 'insanity is also linked to physiological conditions' and therefore to normal conditions, and that 'love in the insane reproduces the tendencies_-but exaggerating such tendencies — of the healthy man'. ${ }^{48}$ Just as Livi had argued that mental illness disclosed the deepest nature of man, so too Lombroso believed that by examining the pathological manifestations of sexual desire it was possible to understand normal sexual behaviour. Lombroso pushed these ideas even further: just as it was not possible to draw a clear line between sanity and insanity, it was likewise implausible to separate normal and pathological sexual desire in absolute terms. One reason rendering this separation so difficult was the fact that sexual perversions belonged to each person's history, and therefore to the (normal) individual's history. Indeed, as Lombroso elaborated, just as necrophilia recalls the violent love that our ancestors felt at the origin of humankind, and eroto-maniacal love is an exaggeration of the platonic form of love, so too 'inverted love reminds us of Lesbian and Socratic horrors and it explains them, and perhaps sexual inversion goes further as it is linked to that hermaphroditism that Darwin recognised in our earliest ancestors'. ${ }^{49}$ Lombroso then linked sexual inversion to 'the hermaphroditism of the foetal period' ${ }^{50}$ This last remark may well have been based on recent observations of the sexually undifferentiated embryo in the first weeks of gestation. ${ }^{51}$

In Lombroso's article, sexual deviations were explained by means of evolution theory and, in particular, by the concept of atavism. There were various theories of atavism current in Italy, but in all of them the behaviour of deviants, be they criminal or insane, was compared to that of primitive man. ${ }^{52}$ Primitive behaviour resurfaced in the form of deviancy in modern civilised man. Interestingly enough, if, as Lombroso believed, the sexual invert represented a regression to a primitive type, then it was also possible to argue that all individuals nursed a dormant sexual inversion, since he believed that same-sex desires were common in the

\footnotetext{
${ }^{46}$ Richard von Krafft-Ebing, 'Über gewisse Anomalies des Geschlechtstriebs und die klinisch-forensich Verwertung derselben als eines wahrscheinlich funktionellen Degenerationszeichens des centralen Nervensystems', Archiv für Psychiatrie und Nervenkrankheiten, 1877, 7, 291-312.

${ }^{47}$ Cesare Lombroso, 'L'amore nei pazzi', Archivio di psichiatria, scienze penali ed antropologia criminale per servire allo studio dell'uomo alienato e delinquente, $1881,2,1-32$.
}

${ }^{48}$ Ibid., 30. On the study of pathology as a means to understanding the normal in Lombroso's medical lecture: Luigi Bulfaretti, Cesare Lombroso (Turin: UTET, 1975), 124.

${ }^{49}$ Lombroso, 'L'amore', 31-2.

${ }^{50} \mathrm{lbid}$.

${ }^{51}$ Frank Sulloway, Freud, Biologist of the Mind: Beyond the Psychoanalytic Legend (Cambridge, MA: Harvard University Press, 1992), 290-6.

${ }^{52}$ S. Nicasi, 'Atavismo: patologia di un ritorno', Ferro, Passioni, 363-71. 
remote past of humanity. ${ }^{53}$ At this stage, however, Lombroso did not pursue this further extrapolation from his basic argument.

Atavism was only one of the various evolutionary theories enabling psychiatrists to expound the development of the sexual perversions. ${ }^{54}$ To complicate the medical understanding of human sexuality, in the 1880s the concept of degenerative hereditary mental disorders won the day in European psychiatry, especially on the Continent. Degeneration was first associated with sexual abnormalities, in particular with sexual inversion, by Krafft-Ebing in 1877, and from then on became the general framework with which to explain sexual psychopathologies up until the very end of the nineteenth century. ${ }^{55}$ Tamassia had followed Krafft-Ebing's 1877 definition of sexual inversion as a pathology, endorsing the German sexologist's description of same-sex desire as a 'serious functional degeneration'. 56

In Italy, the intricate relationship between atavism, various evolutionary theories, and degeneration when used to explain human sexuality can be seen in Enrico Morselli's treatise, the Manuale semejotica delle malattie mentali [Manual of Semiotics of Mental IIIness] (1885-89), which was the first Italian psychiatric treatise to deal systematically with sexual inversion. Morselli, who, as I mentioned earlier, founded the Rivista sperimentale difreniatria with Livi and Tamburini, was less internationally renowned than Lombroso, but was nonetheless an important figure in Italian medical circles. Although a proponent of organicist psychiatry, Morselli considered psychological investigation to be of the utmost importance within his discipline. ${ }^{57}$ Like his colleagues Livi and Lombroso, Morselli believed that the study of the pathological and that of the normal were closely interwoven, and thought that 'each individual mind, when in a morbid state, must be compared to that which it was or should have been in its normal state..$^{58}$

In his Manuale di semejotica delle malattie mentali, Morselli discussed same-sex desires in the context of a more general theory of the reproductive instinct. Like Charles Darwin and Krafft-Ebing before him, Morselli believed that in nature animals have two basic instincts: self-preservation and gratification of the sexual instinct. Darwin had previously paid attention to these in 1871 when, in his The Descent of Man, he put forward the theory of sexual selection. According to Darwin, in some instances competition between members of the same species is for mates rather than for food or living space. ${ }^{59}$ Krafft-Ebing endorsed selfpreservation and sexual gratification as the only two instinctual aims known to human physiology. In his celebrated Lehrbuch der Psychiatrie [Textbook of Psychiatry, 1879] and later in Psychopathia Sexualis (1886), Krafft-Ebing traced the most basic features of human

${ }^{53}$ Lombroso argued this some years later: Cesare Lombroso, 'Du parallélisme entre I'homosexualité et la criminalité innée', Archiv. Psich., 1906, 27, 378-81.

${ }^{54}$ Under Lombroso's influence atavism was especially widely employed within Italian psychiatric circles, although it was also adopted to varying extents outside Italy to explain sexual deviancy. Ivan Crozier, 'La sexologie et la definition du "normal" entre 1860 et 1900', Cahiers du genre, 2003, 34, 25-8.

${ }^{55} \mathrm{Krafft}-E b b i n g$, 'Über gewisse Anomalies'.

${ }^{56}$ Tamassia, 'Sull'inversione', 117.
${ }^{57}$ Patrizia Guarnieri, Individualità difformi: la psichiatria antropologica di Enrico Morselli (Milan: Claudio Angeli, 1986), 86-7. His manual betrays a shift from a more organicist position (first volume) to a more psychological psychiatry (second volume). Patrizia Guarnieri, 'Between Soma and Psyche: Morselli and Psychiatry in Late-Nineteenth-Century Italy', Porter et al., The Anatomy of Madness, III, 102-24.

${ }^{58}$ Guarnieri, 'Between Soma', 112.

${ }^{59}$ Charles Darwin, The Descent of Man, and Selection in Relation to Sex (Princeton, NJ: Princeton University Press, 1981), part 2. 
psychopathology to the vicissitudes and perversions of these two fundamental drives of life. ${ }^{60}$ Drawing on Darwin and Krafft-Ebing, Morselli likewise argued that the reproductive instinct is stronger than the self-preservation instinct, and in addition emphasised the dominant role of the sexual instinct in the psychological life of human beings. ${ }^{61}$ Morselli explained that the sexual function was a critical part of human health because it was the origin of a vast array of feelings, thoughts, and tendencies; this in turn meant that if the sexual instinct proved to be in any way anomalous, it could generate morbid manifestations across a wide spectrum of behaviours, practices, and feelings. Moreover, in humankind, the reproductive function triggered a wide range of psychological needs, some of which could lead to the appearance of sexual perversions. As a result of the process of civilisation, the brain had developed beyond the individual's natural physiological needs, and this fact also gave rise to sexual perversions. According to Morselli, it was difficult to say exactly when the sexual instinct stopped being a natural manifestation and turned morbid, but it was certain that modern civilisation was consistently to blame for sexual deviancies. ${ }^{62}$

Morselli drew in particular on two evolutionary theories to frame the above ideas, namely, those of the German biologist and physician, Ernst Haeckel, and Lombroso's theory of atavism. Building on Haeckel, Morselli proposed a phylogenetic explanation that accounted for both normal and deviant sexualities. ${ }^{63}$ Human development was, Morselli claimed, characterised by an ontogenetic process of sexual differentiation, which mimicked the phylogenetic evolution from original primitive bisexuality to the monosexuality of civilized man. As part of the normal development of the human organism, the original bisexual disposition was replaced by monosexuality, which was reinforced by an increasing differentiation of male and female secondary sexual characteristics; the recessive sex retaining only a few abortive signs (such as facial hair on females). Morselli also employed Lombroso's idea of atavism, when, for example, pointing out that although there had been 'unnatural intercourses' throughout human history, in modern times they were to be considered a result of atavism. ${ }^{64}$ Sexual perversion was caused by obsessive morbid impulses and represented 'stigmata of degeneration'. At the same time Morselli acknowledged that sexual perversions could also be acquired within a single lifetime, although environmental factors could only make an inherent predisposition become manifest. Morselli specified that in the higher social strata in particular, sexual perversion was the result of vicious habits: civilisation stimulated the development of refined libidinal tendencies and allowed them to be exercised for too long. ${ }^{65}$ In Morselli's system, therefore, sexual perversion could be caused either by morbid heredity or by a corrupt environment, but in the latter case this was only possible in those individuals who were already tainted by degeneration. The adoption of both a hereditary and an environmental explanation was not uncommon among the Italian medical doctors who worked on sexual psychopathies. As I have recently shown elsewhere, biological, social and psychological factors were all used to explain sexual inversion in the late nineteenth century. ${ }^{66}$ Sometimes one of these factors was predominant, while at other times, all three coexisted.

\footnotetext{
${ }^{60}$ Sulloway, Freud, 253-4; Darwin, Descent, part 2; Krafft-Ebing, Psicopatie sessuali.

${ }^{61}$ Enrico Morselli, Manuale di semejotica delle malattie mentali (Milan: Vallardi, 1885-1889), 213.

${ }^{62}$ Ibid., 213-14.
}

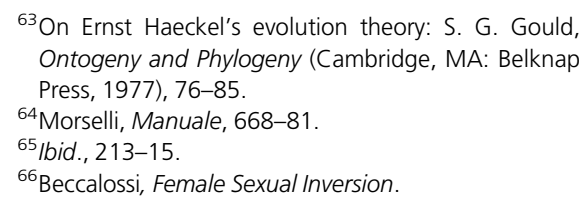


Although Morselli was unable to draw a clear line between normal and pathological sexual behaviours - it being difficult to say exactly where and when morbid elements arose in sexual perversions-he nevertheless attempted to classify sexual perversions on the basis of their deviation from heterosexual intercourse. He surveyed, for example, masturbation, pederasty, sodomy, and bestiality. Special attention was devoted to sexual inversion, which was defined as a 'psychic degeneration' and as an 'anomaly' of the sexual instinct. ${ }^{67}$ In Morselli's classification of the sexual perversions, sexual inversion was included in the broader category of 'parafrenie', anomalies of constitutional development associated with brain lesions. In the late 1860s Griesinger and Westphal had hypothesised that same-sex desires were an innate condition and linked brain lesions to sexual perversions. ${ }^{68}$ By the second half of the 1880s, an Austrian and German theoretical tradition had been consolidated, whereby non-reproductive sexual behaviour, and in particular same-sex desires, were linked to certain unspecified brain lesions. This German-language tradition, which had laid the foundations of European sexology, was well known to Morselli, as is plain from his references to Krafft-Ebing - who, as historians of sexology have shown, had elaborated Griesinger and Westphal's studies on sexual inversion. ${ }^{69}$ Interestingly enough, when expounding his classification of sexual perversions, Morselli did not refer to the German tradition; instead, he invoked the older French tradition of Pinel and Esquirol. In Morselli's nosology, 'parafrenie' included criminal psychosis, 'semi-insanity' (individuals classified as 'mattoidi'), and folies raisonnantes. ${ }^{70}$ As highlighted earlier, Esquirol's monomania and Prichard's moral insanity were folies raisonnantes, insanities that did not manifest any impairment of the intellectual function.

Thus, the first Italian psychiatric treatise to deal systematically with sexual inversion did not define it as a 'mental pathology' in the strictest sense of the term. Indeed, Morselli considered sexual inversion to be an 'anomaly' of the sexual instinct. At this point it is important to explain a taxonomical matter. In the 1880 s a critical issue around the conceptualisation and classification of mental disorders was introduced into Italian psychiatry. Within debates on different classificatory systems relevant not only for the understanding, but also for the treatment, of insanity, psychiatrists explicitly addressed the distinction between 'constitutional abnormality' and 'mental pathology'. ${ }^{71}$ In some psychiatric disorders, such as sexual inversion (or moral insanity), the absence of an alteration in the intellectual faculties characterised what was called constitutional anomaly or abnormality, which was deemed untreatable precisely because it was constitutional. The distinction between anomaly and mental pathology turned upon the degree of impairment of the intellectual faculty and of the brain. Whereas in the 1870s a number of psychiatrists classified moral insanity as a mental disorder, in the 1880 s an increasing number of Italian psychiatrists, including Morselli, classified it as a constitutional anomaly. ${ }^{72}$ Moral insanity belonged to the same group as sexual inversion. If,

\footnotetext{
${ }^{67}$ Morselli, Manuale, 667-81.

${ }^{68}$ Harry Oosterhuis, Stepchildren of Nature: Krafft-Ebing, Psychiatry and the Making of Sexual Identity (Chicago: University of Chicago Press, 2000), 47-53.

${ }^{69} \mathrm{lbid}$. Morselli at the time knew Griesinger's general work on mental illness as caused by brain lesions, see Guarnieri, 'Morselli', Anatomy of Madness, 113. In his Manuale, Morselli accepted Theodor Hermann Meynert's definition of madness as the result of brain
}

lesions. Meynert, a German-Austrian neuropathologist and anatomist, is known as one of the founders of brain psychiatry.

${ }^{70}$ Morselli, Manuale, 666-83. See also Eugenio Tanzi, Trattato delle Malattie Mentali (Milan: Soc. Ed. Libraria, 1905), 247-8.

${ }^{71} \mathrm{U}$. Fornari, 'Evolizione del concetto di monomania', Ferro, Passioni, 475-6.

${ }^{72}$ Ibid., 487. 
therefore, in the 1880s moral insanity could not be considered a mental pathology, homosexuality could not be regarded as such either.

A clear definition of constitutional anomaly can be found in the writings of Eugenio Tanzi, who was studying moral insanity in the 1880s. As Professor of Psychiatry at the University of Florence, Tanzi became one of the most prominent Italian psychiatrists at the turn of the twentieth century. ${ }^{73}$ In 1884, writing in the Rivista sperimentale di freniatria, Tanzi explained that the individual affected by so-called moral insanity was not, in strict terms, insane. Moral insanity 'has the relative value of a constitutional anomaly of the personality, it is of hereditary origin, of a neurotic constitution, linked to other forms of anthropological degeneration, but it is not necessarily linked to damaged intellectual functions, therefore it is different from insanity'. ${ }^{74}$ This certainly did not mean that psychiatrists like Morselli, when, in the 1880s, they classified sexual inversion as a constitutional anomaly, thought that same-sex desires were a normal phenomenon. Nevertheless, whereas in 1878 Tamassia had strongly argued that sexual inversion was a pathology, by the second half of the 1880s Morselli was locating sexual inversion in a grey zone between pathology and normality. The same condition was ostensibly less severe than it had been only ten years earlier, and now the category of constitutional anomaly allowed psychiatrists to suppose that the intellectual functions of sexual inverts were in perfectly good order.

\section{The Blurred Boundary between the Normal and the Abnormal Sexual Instinct}

As noted above, Morselli believed that the reproductive instinct was stronger than that of self-preservation, and that the manifestations of the sexual instinct had a major impact on a human being's psychological life. The reproductive physiological function was the norm to which sexual variations were compared. Pleasure did not have any role in Morselli's Manuale di semejotica delle malattie mentali. Not all psychiatrists engaged with the nascent medical branch of sexology agreed that reproduction was the critical element in the sexual instinct; some, indeed, granted a certain role to sexual pleasure. In this final section I will explore psychiatric debates as to whether reproduction or sexual pleasure were the principal aims of the normal sexual instinct, and I will further consider how these debates could suggest that homosexuality was not a pathology, but an abnormality, and how in some cases it could even be considered a normal phenomenon.

In 1890, Guglielmo Cantarano, Professor at the University of Naples and director of the Neapolitan asylum, published a study on sexual inversion. His interest in the topic dated back to the early 1880s, when he had published the first Italian case history of a female invert. $^{75}$ In his 1890 study, however, one of the critical issues he addressed was how sexual perversions differed from the normal sexual instinct. According to Cantarano, perversions of the sexual instinct could be considered 'necessary, slight nuances' that served to enhance sexual excitement, and were so widespread that, to a certain extent, they could not be considered 'abnormal'. It was indeed difficult to establish a clear boundary

\footnotetext{
${ }^{73}$ R. Boeri et al., 'Eugenio Tanzi (1856-1934) and the Beginning of European Neurology', Journal of the History of Neurosciences, 1994, 3, 177-85.

${ }^{74}$ Eugenio Tanzi, 'Pazzi morali e delinquenti nati', extract from Rivista sperimentale di freniatria e di medicina
}

legale in relazione con l'antropologia e le scienze giuridiche e sociali, 1885, 23. Originally published in 1884.

${ }^{75}$ Beccalossi, Female Sexual Inversion, 62-6. 
between the normal and abnormal in sexual matters. ${ }^{76}$ He reported earlier attempts by French psychiatrists to classify sexual perversions, ranging from that of the physician ClaudeFrançois Michéa, in 1849, to the more recent study by Valentin Magnan in 1885, which had hypothesised a neuroanatomical origin for sexual perversion. ${ }^{77}$ Cantarano thought that a classification based on the way in which sexual manifestations differed from the norm might allow physicians to understand sexual perversions. ${ }^{78}$ Contrary to many of his colleagues, who took for granted the correlation of the normal sexual instinct with the reproductive instinct, Cantarano not only disagreed with this position, but also made explicit what he meant by the 'physiological concept' of the 'norm' in sexual matters. Before even entering into the details of his taxonomical system, Cantarano thus clarified that 'the [normal] sexual instinct includes in its scope the search for the opposite sex and of the same species, with which it is possible to enter into genital intercourse for the purposes of reciprocal enjoyment. ${ }^{79}$

As Cantarano continued to highlight in the course of his study, the critical elements in the normal sexual instinct were, first, the search for the opposite sex, and second, reciprocal enjoyment through genital intercourse. If one of these elements was missing in the expression of the sexual instinct, it was possible to speak of actual 'sexual perversion'. Cantarano explained that he did not include among the essential elements of the sexual instinct the continuation of the 'race', because it was not the indispensable goal of orgasm, nor was reproduction often a consequence. Indeed, men quite often tried to avoid reproduction, resorting to all possible methods, without sexual pleasure being affected. ${ }^{80}$ Finally, Cantarano classified sexual perversions according to the way in which they differed from the normal sexual instinct: perversions caused by unusual memory associations such as flagellation or cunnilingus; perversions without reciprocal pleasure such as torture, rape and killing; sexual inversion; bestiality, azofilia (desire towards a lifeless object); and what he called 'essential onanism'. 81

Whereas for Cantarano questioning the boundary between the normal and the abnormal sexual instinct resulted in a clear definition of sexual inversion as abnormal instinct, some early twentieth-century studies moved the boundary still further. This trend can be found in a number of major Italian psychiatric textbooks, among them Leonardo Bianchi's Trattato di psichiatria [Treatise of Psychiatry] (1904); Tanzi's Trattato delle malattie mentali [Treatise of Mental IIIness] (1905) and Sante De Sanctis' Trattato di medicina sociale [Social Medicine Treatise] (1911). ${ }^{82}$ I will focus on Tanzi's treatise because, more than other works, it directly addresses the question about boundaries between normal and abnormal within psychiatry while at the same time manifestly shifting this boundary. In his Treatise, Tanzi devoted a

\footnotetext{
${ }^{76}$ Guglielmo Cantarano, 'Inversione e pervertimenti delI'istinto sessuale', La Psichiatria, 1890, 8, 281.

${ }^{77}$ C. F. Michéa, 'Des deviations del'appétit vénérien', Union Medicale, 1849, 3 July, 338-9; Valentin Magnan, 'Des anomalies, des aberrations et des perversions sexuelles', Progrès médicale, 1885, 13, 49-50, 65-8, 84-6; Cantarano, 'Inversione e pervertimenti dell'istinto sessuale', 275-9. On French studies on sexual inversion: Vernon A. Rosario, The Erotic Imagination: French Histories of Perversity (Oxford: Oxford University Press, 1997).

${ }^{78}$ Cantarano, 'Inversione', 280.
}

\footnotetext{
${ }^{79} \mathrm{lbid}$.

${ }^{80} \mathrm{lbid}$.

${ }^{81}$ Ibid., 289.

${ }^{82}$ Leonardo Bianchi, Trattato di psichiatria (Naples: Pasquale 1904), 619-27; Eugenio Tanzi, Trattato delle Malattie Mentali (Milan: Soc. Ed. Libraria, 1905), 618-36; Sante De Sanctis, Trattato di medicina sociale. Patologia e profilassi mentale (Milan: Vallardi, 1911), 79-95. On how these psychiatrists classified homosexuality: Beccalossi, Female Sexual Inversion, 55-62.
} 
chapter to the problem of the classification of mental illnesses. ${ }^{83}$ Before expounding his taxonomic system, Tanzi enquired what psychiatrists should include within the domain of insanity. If psychiatry ought to concern itself only with 'lunatics in the strict sense of the term', and if by insanity psychiatrists had to understand a disease of the whole human personality, as Morselli for example supposed, it was clear that certain psychopathic states would not fall within the province of the psychiatrist. Sexual inversion and other anomalies of the character-being 'extreme deviations' of the human type, and therefore not in the psychiatric domain at all—would instead belong, Tanzi judged, to the essentially psychological sphere of anthropology. ${ }^{84}$

Yet Tanzi believed that it was not appropriate to narrow down the field of psychiatry. Every disease that had as its typical manifestation the blunting of the intelligence or a change in character, every unaccountable change of disposition, every reaction of the will that was inadequate, unusual or unreasonable, belonged by rights to psychiatry, even though they did not lead to the disintegration of the psychic personality. Tanzi conceded that normal people displayed variations of the personality on an everyday basis, but specified that only 'extraordinary and radical transformations of the personality' were pathological in a strict sense. ${ }^{85}$ Paranoia, hysteria, constitutional immorality, and sexual inversion were not 'true diseases', but rather 'inherent anomalies of the mental development' that were nevertheless to be regarded as indicative of a 'decay of the stock'. These patients often wavered between disease and normality. ${ }^{86}$ They were weak individuals, but they were in full possession of their intellectual faculties. They were abnormal, but not insane.

Tanzi reflected on the significance of blurring boundaries not only with regard to the psychiatric domain and the inclusion or exclusion of certain mental anomalies, but also with regard to sexual perversions. He stressed that not every irregularity of the erotic life and sexual desire was to be regarded as an infallible sign of sexual perversion. While the norm of the erotic action was reproduction, those 'aberrations of the genetic sense of a partial and transient nature' did not necessarily indicate an 'anthropological anomaly'. The critical element was that procreation was not systematically 'betrayed' ${ }^{87}$

Love is the least controllable and most free of human passions, because the instinct from which it emanates is blind, imperious, and only slightly conscious, or quite unconscious, of the physiological objective at which it is directed. A problem so indeterminate allows of a certain variety of personal solutions, and in amorous matters every man may be said to have a right to an aesthetic of his own. This right has, however, its limit, and its exercise should not be allowed to result in the natural and advantageous attraction to the opposite sex being displaced by immoral and fruitless tendencies. ${ }^{88}$

Following the medical beliefs of the time, Tanzi thought that homosexuality could be congenital or acquired, but specified that even acquired homosexuality was still due to a

\footnotetext{
${ }^{83}$ Since the birth of the Italian Psychiatric Society, one of its main concerns was to elaborate a formal system allowing for the official classification of mental disorders to adopt on a national scale. This prompted lively debate within the Italian medical community.
}

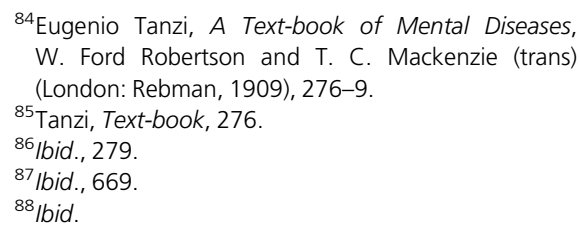


'constitutional anomaly', an organic weakness in the body. ${ }^{89}$ In other words, for Tanzi, as for Morselli, only weak individuals with degenerate constitutions could develop any form of sexual inversion. In most instances erotic attraction to persons of the same sex was a 'manifestation of Daltonism' that depended on 'imperfect vision' of the normal object of the amorous passion. For instance, this sexual Daltonism could be observed in adolescents who lived in a single-sex college. Among all possible sexual perversions, then, schools and colleges would be assumed to be most likely to foster homosexuality. There were several factors that contributed to the emergence of sexual inversion, and Tanzi laid particular emphasis upon the critical role of the memory for the outcome of sexual inversion. Memory lent an irresistible charm to erotic impressions from childhood. ${ }^{90}$ If the first sexual experiences and pleasures were associated with members of the same sex, the recollections of such experiences, combined with a life of seclusion and with the chance to magnify and perpetuate the initial erotic attractions, explained sexual inversion in environments such as colleges. ${ }^{91}$

Tanzi subsequently made a number of radical claims. He argued that, in themselves, same-sex desires in schools or colleges were not a mental disorder or even an anomaly, because they were transitory. Yet the corrupt tendency became a 'true constitutional anomaly' if, coincident with the early and intense arousal of the sexual instinct, it acquired 'stability' and throughout life barred the way to physical acts essential to 'physiological love'. This represented an 'arrest of the genetic instinct at the infantile stage — an erotic infantilism that did not lessen the strength of sexual attraction, but which prevented it from taking a 'normal direction'. Interestingly enough, Tanzi believed that a young man who temporarily feels himself to be in love with a youth with feminine features did not prove himself to be effeminate, but 'ultra-virile'. The significance of these 'aberrations' was 'hyper-physiological', that is to say, exceptionally normal. True constitutional perversion was reached when the adolescent persisted in same-sex acts even when he had had the opportunity to engage in relations with the opposite sex. In this case the individual attained a complete and 'irremediable inversion'. Therefore, 'the temporary ideal becomes definite, absorbing, absolute, and monstrous'. ${ }^{92}$ The true perversion occurred only when a 'false orientation of the genetic function' rendered 'normal contact impossible, difficult, or repugnant', while it made 'abnormal contacts easy, pleasing or strongly desired. ${ }^{.93}$ Noticing that sexual inversion occurred sometimes in one and the same family, Tanzi hypothesised that 'pathological heredity transmits only the nervous and the moral degeneration', and therefore the constitutional weakness, so that particular individuals were predisposed to have certain sexual preferences. Indeed, sexual inversion, along with constitutional immorality, paranoia and intellectual feebleness, belonged to a group of 'degenerative mental anomalies'. ${ }^{94}$ Yet homosexuality within the same family depended more on its members having had a similar education.

Therefore, in his 1905 aetiology of sexual inversion, Tanzi linked the individual's 'weak' constitution to same-sex desires. While not abandoning physical explanations, he paid significant attention to psychological factors that contributed to the emergence of homosexuality. A few years later in another manual, Psichiatria forense [Forensic Psychiatry]

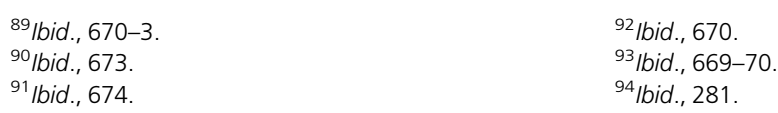


(1911), Tanzi jettisoned all physical explanations of sexual inversion. He now maintained that homosexuality had only a 'psychological origin'. He even rejected the concept of congenital inversion accepted by most psychiatrists until the end of the nineteenth century and argued that same-sex desires were merely due to erroneous 'mental associations'. ${ }^{95}$ During their childhood some individuals associated a pleasurable feeling with individuals of the same sex, and this association remained stable in the individual's memory. Tanzi also pointed out that most male inverts were virile and sought out other virile men, while most of the female inverts were feminine and desired similar women. According to Tanzi, this supported his idea that homosexuality did not have a bodily origin, but was the result exclusively of psychological causes. ${ }^{96}$

Tanzi's gradual abandonment of a congenital explanation of homosexuality is representative of a wider phenomenon. At the turn of the century, inversion was still considered congenital, a 'constitutional anomaly', an arrest of cerebral-psychic development, or a 'psychic degeneration', to quote some of the most common terms in early twentieth-century psychiatric manuals. However, during this same period, Italian psychiatrists displayed a growing interest in the mechanisms of mental association and memory, and in the influence of the environment upon mental development. While they insisted that both congenital and acquired inversions were caused by a constitutional weakness or degeneration, Italian psychiatrists seemed to invest more energy in understanding acquired homosexuality. This new approach to sexual inversion privileged the study of the individual's environment and early life. This transition led to a further crucial shift in medical writing: the boundary between normal and abnormal moved and same-sex desires were now considered normal phenomena, at least until puberty, and even during adulthood in specific circumstances.

Tanzi's explanation of sexual inversion and the ultimate shift in his position is particularly interesting because it illustrates how, at the beginning of the twentieth century, the theory of degeneration had become insufficient to explain deviant sexualities. As the Neapolitan sexologist, Pasquale Penta, explained, at the dawn of the new century degeneration theory had been increasingly criticised within psychiatric circles. It was acknowledged that it had become a meaningless concept. ${ }^{97}$ At the same time, Italian medical writers studying the functioning of the sexual instinct embraced psychological studies in an attempt to overcome the failure of degeneration theory to provide a comprehensive account of a wide range of sexual phenomena. Amongst the more popular psychological accounts, Alfred Binet's use of fetishism to understand sexual inversion and other sexual perversions was of particular interest to Italian psychiatrists. At the end of the 1880s, the French psychologist had furnished an explanation of sexual arousal provoked by non-living objects. Basing his observations on the phenomenon of 'fetishism' (a term he coined himself), Binet had argued that prevailing medical accounts of sexual perversion, phrased in hereditary terms, did not solve the more fundamental problem of how such aberrations had been acquired in the first place. ${ }^{98}$ Binet argued that sexual psychopathologies such as fetishism and

\footnotetext{
${ }^{95}$ Eugenio Tanzi, Psichiatria forense (Milan: Vallardi, 1911), 247-54.

${ }^{96} / \mathrm{bid}$.

${ }^{97}$ Pasquale Penta, 'L'origine e la patogenesi della inversione sessuale, secondo Krafft-Ebing e gli altri autori', Archivio delle psicopatie sessuali, 1896, 54.
}

\footnotetext{
${ }^{98}$ The phenomenon of fetishism had been observed in psychiatric research on sexual perversions, for example in Lombroso's 1881 abovementioned article, and in ethnological and historical works on religion. So Binet only coined it as a psychiatric category.
} 
sexual inversion were psychologically acquired by accidental exposure to events in early childhood. For instance, according to Binet, in individuals predisposed by heredity, when the first lively sexual excitement during childhood coincided with the sight or touch of a person of the same sex, it gave rise to a 'stable association', resulting in a predisposition to sexual inversion. ${ }^{99}$ Thus, sexual inversion arose when there was an association between certain accidental experiences and pleasurable feelings. Tanzi's account of the working of memory and the importance of mental associations in childhood testify to Binet's influence at the turn of the nineteenth century in Italy.

\section{Conclusion}

This article has shown how a number of late eighteenth- and early nineteenth-century medical developments shaped an epistemological framework that allowed certain psychiatrists to problematise any clear-cut distinction between normal and pathological sexuality. Nineteenth-century Italian psychiatry appears to have been open to a number of theoretical undercurrents that served to blur the boundary between normal and abnormal in specific ways. In other countries medical debates may likewise have mobilised a number of other traditions serving to frame the reproductive and non-reproductive sexual instinct as not qualitatively different. One only has to consider the case of France, where in 1887 Binet, in his study of fetishism, came to argue that a perversion was nothing but an exaggeration of the normal manifestation of love, the difference between the normal and the pathological being only a matter of degree. ${ }^{100}$

As to the specificities of the Italian context, psychiatrists were certainly committed to demarcating three psychiatric domains and to understanding where non-reproductive sexual instinct should be located, whether in the normal, the abnormal or the pathological realms. In late nineteenth-century Italian psychiatry, terms like 'anomaly', 'abnormality' or 'pathology' were sometimes used as overlapping categories, or at the very least as relating to each other. The boundary between abnormality and pathology was not clear-cut, but nor was the boundary between abnormal and normal either. 'Abnormal', in particular, was a slippery concept, a grey zone that could contain the normal or the pathological. This ambiguity in the terminology was reinforced by the fact that while psychiatrists routinely provided definitions of the pathological, they rarely spelled out what 'normal' meant. For psychiatrists it was also difficult to draw clear-cut lines between these categories because, up until the end of the nineteenth century, they thought that insanity could be found along the same spectrum as the healthy state; indeed, insanity allowed psychiatrists to understand normal intellectual functions and the inner states of the human mind. In line with this, the study of sexual perversions allowed psychiatrists to comprehend normal sexuality, which was strongly linked to reproduction. Debates about the blurred boundary between normality, abnormality, and pathology had further implications. Psychiatrists like Tanzi, who highlighted the imprecision of psychiatric nosologies and stressed how difficult it was to draw a line between normal and abnormal phenomena, attempted to develop a psychiatric

\footnotetext{
${ }^{99}$ Alfred Binet, 'Le fétichisme dans I'amour', Revue Philosophique, 1887, 24, 143-167; 252-274.

${ }^{100}$ Robert A. Nye, 'The Medical Origins of Sexual Fetishism' in Emily Apter and William Pietz, eds, Fetishism as
}

Cultural Discourse (Ithaca and London: Cornell University Press 1993), 13-30. 
classification and diagnoses based on symptoms. As a profession, however, psychiatry was in doubt as to the precise pathological process underlying such symptoms, and could not attain the same degree of certainty as, for example, physicians working with anatomical and physiopathological data. This predicament created, and still creates, uncertainty in psychiatry.

Whereas in 1878, on the basis of a case history he had analysed, Tamassia had argued that sexual inversion was a pathology, in 1885, in his important psychiatric textbook, Morselli classified sexual inversion as an 'abnormal disorder', a 'psychic degeneration' and an 'arrest of cerebral development'. In strict terms sexual inversion was not a mental pathology, but in the 1880 s psychiatrists were certainly not prepared to say that it constituted a normal behaviour, despite the instability of psychiatric taxonomic systems adopted at the time. Nonetheless, at the turn of the century Italian psychiatrists tended to hedge their bets and suggested that sexual inversion was both a mental abnormality and a normal form of behaviour if it occurred in a single-sex environment before or during adolescence. The critical element in this distinction was the transitory aspect of the phenomena of same-sex desires. Ultimately, this was just another way to reaffirm the norm of reproduction. Sexual conduct was permitted a modicum of variation and transgression, but the role of reproduction had in the last analysis been reaffirmed. Yet, to a certain extent in single-sex environments and before puberty, same-sex desires became normalised.

At the beginning of the twentieth century, Tanzi's explanations of sexual inversion illustrate how the theory of degeneration had proved insufficient to account for deviant sexualities. Degenerationist or organicist theories were increasingly judged to be inadequate when it came to explaining homosexuality, and psychiatrists turned more and more towards the childhood of sexual inverts for answers. This interest in the early life of patients was already present in the first case-histories sexologists had published in the late 1870s, but at the turn of the century this concern intensified, testifying to an increased awareness in the wider world of psychological and environmental explanations of same-sex desires. The development of psychiatry and sexology also had a part to play in the 'de-pathologisation' of sexual inversion in a number of specific contexts. Thus, when psychiatrists began to investigate sexual inversion in the 1870s, they mainly focused on case histories of subjects found in asylums and prisons. In the 1890s, however, they began to reformulate their object of study to encompass individuals who were not on the margins of society, a strategy reflecting their readiness to extend their domain. ${ }^{101}$ Having conceded that a sexual abnormality such as 'sexual inversion' did not fall within psychiatry's domain in the strictest sense, Tanzi thus went ahead and explored the subject all the same. Since Livi had published his programmatic article in 1875, it had been clear that Italian psychiatrists were highly ambitious, and did not want to remain confined within the walls of the asylum. They could contribute, or so they reckoned, to the understanding and management of the entire (normal) society.

${ }^{101}$ It is well known that Michel Foucault has argued that from the eighteenth century medical experts made an effort to distinguish and classify various non-marital sexual practices and that this knowledge did not aim to repress sexuality, but was essentially a means to expand the study of sexuality to a number of different realms. In brief, the medicalisation of sexuality extended the power of medical knowledge, and therefore of the medical profession. Michel Foucault, The Will to Knowledge, History of Sexuality, vol. 1, Robert Hurley (trans) (Harmondsworth: Penguin Books, 1998). By looking at debates on homosexuality, it is apparent that Italian psychiatrists were extending their domain in the 1890s. 
Same-sex desires had entered the domain of the normal, but this meant that 'normal' contexts now also had to be closely scrutinised. ${ }^{102}$

Finally, French psychiatry continued to exert a strong hold over Italian psychiatry, with early nineteenth-century debates on folies rasonnantes resonating until the end of the century. Historians have shown that from the 1870s Italian psychiatrists discussed at length partial insanities, and likewise moral insanities. ${ }^{103}$ Early nineteenth-century insanities without delusions were characterised by certain features that came to be typical of what was later defined as psychopathy. Both insanity without delirium and psychopathy were characterised by instability of the emotions in conjunction with intact intellectual functions, and various sexual perversions, such as sexual inversion, were grouped together as psychopathies. In the 1880s, Italian psychiatrists considered psychopathies to be anomalies, not mental pathologies. The importance of this nosological nuance has been underestimated by historians. Only within the framework of the psychopathologies were certain sexologists emboldened to think that sexual inverts were not completely mad, and able to function intellectually. Remarkably enough, at the turn of the century, homosexuality was even considered normal in certain circumstances, such as single-sex environments.

It then took another seventy years for psychiatrists to declare officially that homosexuality was not a mental disorder at all. Homosexuality was removed from the American Psychiatric Association's Diagnostic and Statistical Manual (DSM) in the 1970s, although until recently the DSM has covered the so-called 'gender identification disorders'. Ironically, these disorders are deemed to start in childhood. While Italian psychiatrists at the beginning of the twentieth century turned a blind eye to the transgressions of the early phases of human life and granted a certain amount of freedom of expression to same-sex desires, the DSM-IV-TR looks carefully at childhood and adolescence. The DSM-IV-TR talks about 'gender identity disorders' which can be detected in boys in the guise of a 'marked preoccupation with traditionally feminine activities' like 'playing house' or playing with Barbie. ${ }^{104}$ Certainly, the DSM-IV-TR avoids mentioning same-sex desires, and yet childhood behaviours are subjugated to supposedly feminine and masculine conventional roles. In current official psychiatric discourses childhood and adolescence are less free than they were one hundred years ago.

\section{Acknowledgements}

I would like to thank those who commented on different parts of this paper on the occasion of The Natural and the Normal in the History of Sexuality workshop organised by the Centre for the History of European Discourses (University of Queensland) and Centre for the Interdisciplinary Study of Sexuality and Gender in Europe (University of Exeter) and the History of Medicine Seminar Series at the Wellcome Unit for the History of Medicine (University of Oxford). I would also like to thank Ivan Crozier and Jana Funke who read and commented on earlier drafts of this work. Any remaining faults are my own.

\footnotetext{
${ }^{102}$ On how psychiatrists explored same-sex desires in single sex environments such as schools: Beccalossi, Female Sexual Inversion, 73-8.
}

\footnotetext{
${ }^{103}$ Fornari, 'Monomania'.

${ }^{104}$ DSM-IV-TR, 756. This article was accepted for publication prior to release of the DSM 5.
} 